\title{
The partial heat - longest plateau technique: Testing TL dating of Middle and Upper Quaternary volcanic eruptions in the Eifel Area, Germany
}

\author{
Ludwig ZÖLler \& Henrik Blanchard*)
}

\begin{abstract}
Middle and Upper Quaternary volcanic events are often difficult to date, in particular when minerals suitable for ${ }^{40} \mathrm{Ar} /{ }^{39} \mathrm{Ar}$-dating are missing. Here, we present first tests of a newly developed technique to use the thermoluminescence (TL) of maar tephra and crustal xenoliths for dating the eruption event. We take into consideration that resetting of the latent geological TL of country rock fragments during eruption may be incomplete. We therefore develop the "partial heat - longest plateau" (PHLP) technique to approach the inherited TL signal at eruption. This technique can overcome TL age overestimates due to incomplete zeroing, as is demonstrated for some eruptions in the Quaternary Eifel Volcanic Field, Germany, in the time range from 11 to $300 \mathrm{ka}$ old. Although we avoid the often observed strong anomalous fading of volcanic feldspars and other volcanic minerals by using heated country rock xenoliths, we still face the problem of longer-term anomalous fading which may be responsible for apparent age underestimates. The orange-red TL emissions (RTL) of pure fine-grained quartz extracts from crustal xenoliths are also tested from two samples. This approach needs, however, further systematic investigations into the TL characteristics of RTL.
\end{abstract}

[The partial heat - longest plateau technique: Testing TL dating of Middle and Upper Quaternary volcanic eruptions in the Eifel Area, Germany]

Kurzfassung: Vulkanische Ereignisse des mittleren und oberen Quartär sind schwer zu datieren, insbesondere, wenn geeignete Minerale für eine ${ }^{40} \mathrm{Ar} /{ }^{39} \mathrm{Ar}$-Datierung fehlen. Mit diesem Artikel werden erste Tests einer neuen Anwendungsmöglichkeit der TL-Datierung an Maar-Tephra und Xenolithen präsentiert, um derartige Eruptionsvorgänge zu datieren. Hierbei wird berücksichtigt, dass ein Rückstellen des latenten geologischen TL-Signals der Gesteinsfragmente während des Eruptionsvorganges eventuell nur unvollständig erfolgte. Aus diesem Grund wurde die „Partial heat- longest plateau-Technik (PHLP) entwickelt, um genau diesem Problem Rechnung zu tragen. Die neu entwickelte Technik kann helfen, eine Überschätzung von TL-Datierungen infolge der unvollständigen Rücksetzung des TL-Signals zu vermeiden. Dies wird für vulkanische Ablagerungen im Eifel-Vulkanfeld demonstriert, die eine Zeitspanne von 11 bis 300 ka umfassen. Obwohl das Problem starken anomalen Ausheilens des TL Signals vulkanischer Feldspäte und anderer vulkanischer Minerale umgangen wurde, existiert immer noch das Problem einer Unterschätzung geologischer Alter als Folge eines langfristigen anomalen Ausheilens im TL Signal. Die orange-roten TL-Emissionen (RTL) reiner feinkörniger Quarzproben aus Xenolithen wurden an zwei Proben getestet. Dieser Datierungsansatz verlangt jedoch noch weitere systematische Untersuchungen.

Keywords: thermoluminescence, anomalous fading, maar tephra, xenoliths, volcanic eruptions, dating, Eifel Volcanic Field.

\footnotetext{
* Address of authors: L. Zöller, H. Blanchard', Steinmann-Insititut f. Geologie, Mineralogie und Paläontologie, Poppelsdorfer Schloss, D-53115 Bonn. E-Mail: Ludwig.Zoeller@uni-bayreuth.de (corresponding author), henrik.blanchard@web.de. ${ }^{1}$ New adress: Steinmann-Institut für Geologie, Mineralogie und Paläontologie, Universität Bonn, Poppelsdorfer Schloss, 53115 Bonn.
} 


\section{Introduction}

Thermoluminescence (TL) dating has often been tested for volcanic minerals (see, e.g., FATTAHI \& STOKES 2003) but faces the problems of strong anomalous fading of volcanic feldspars (WINTLE 1973) or of very low TL signals from other volcanic minerals except for quartz. The latter is, however, not present in mafic volcanic rocks unless as xenoliths derived from older country-rock in the direct vicinity of the vent. In order to circumvent these problems, we tried to use xenoliths (cf. CHEN et al. 2001) and maar tephra derived from country-rock to date their last resetting during the volcanic activity by TL. This approach, however, raises new problems, in particular the degree of heating during the eruption (cf. GonZÁLEZ et al. 2006 and comments by DulLER 2006) and the question if, besides heating, other events may reset the parent "geological" TL signal of the dated minerals.

We sampled xenoliths derived from Lower Devonian silicoclastic country-rock (partly affected by metamorphism) and maar tephra from several volcanic eruptions in the Quaternary Eifel Volcanic Field, Germany (Fig. 1), separated in two NW-SE oriented sub-fields, the West and the East Eifel Field (MEYer 1986, Schmincke 2000, Büchel et al. 2000). In the West Eifel Field phonolitic eruptions are missing. Hydroclastic maar eruptions occurred in both fields but are more typical for the West

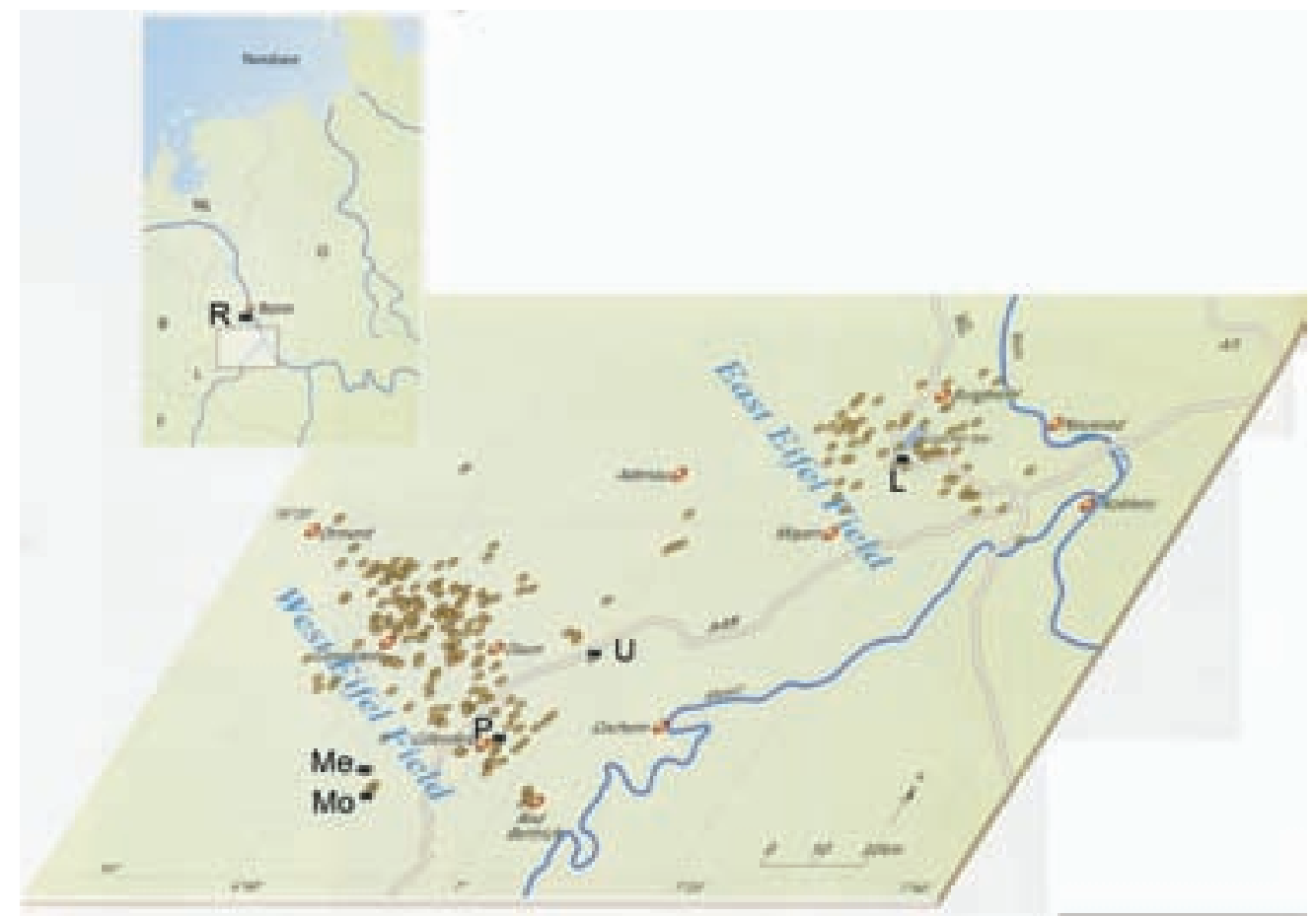

Fig. 1: The Quaternary West and East Eifel Volcanic Fields in the Rhenish Massive, Germany (adopted from SCHMINCKE, 2000). Studied localities shown as black rectangles: Me=Meerfelder Maar (Deudesfeld site), Mo=Mosenberg scoria cone (southernmost cone), L=Lake Maria Laach (Wingertsberg site), $\mathrm{P}=$ Pulvermaar (near Gillenfeld), R=Rodderberg, south of Bonn, $\mathrm{U}=$ Ulmener Maar.

Abb. 1: Quartäre Vulkanfelder der West- und der Osteifel, Rheinisches Schiefergebirge, Deutschland (bearbeitet nach SCHMINCKE, 2000). Schwarze Rechtecke markieren bearbeitete Lokalitäten: Me=Meerfelder Maar (Tuffgrube Deudesfeld), M=Mosenberg-Schlackenkegel (südlichster Kegel), L=Laacher See (WingertsbergWand), $\mathrm{P}=$ Pulvermaar (bei Gillenfeld), $\mathrm{R}=$ Rodderberg südlich Bonn, U=Ulmener Maar. 
Eifel Field where maar tephra consists of up to $>90 \%$ of country rock clasts (mainly Lower Devonian slates, siltstones and quartzites or quartzitic sandstones). In some maar tephras (e.g., Meerfelder Maar) also peridotite xenoliths from the upper mantle with diameters up to ca. $20 \mathrm{~cm}$ can be found which, however, were not used for dating.

The incipient observation for this study was the finding of a few $\mathrm{cm}$ to several $\mathrm{dm}$ thick beds of very well sorted, fine-grained maar tephra in the ramparts of Lake Ulmener Maar and Lake Pulvermaar in the West Eifel Field. These tephra beds consist almost entirely of fine-ground Lower Devonian slate and siltstone clasts with a clear maximum in the silt fraction and very low clay fraction. The grinding of the hard country-rock down to these fine fractions can be explained by the theory of hydroclastic eruptions as presented by LORENZ \& Zimanowski (2000). Preliminary TL measurements from the polymineral fine-grained fraction $(4-11 \mu \mathrm{m})$ using the "multiple aliquot additive dose" (MAAD) protocol (WINTLE 1998, VANDENBERGHE et al. 2004) showed that the $\mathrm{TL}$ and the infra-red stimulated luminescence (IRSL) were totally zeroed at deposition of the two studied maar tephras (ZöLLER et al. 2009). This result is, however, somewhat surprising as zeroing by light exposure in a base surge is certainly insufficient and it must be doubted if thermal zeroing in a hydroclastic eruption is able to completely erase the parent TL. Heat transfer in the eruption chamber of a maar during subsurface grinding of the country-rock is probably low in a dry gas-solid mixture, although the presence of water under high pressure conditions, however, may increase heat transfer (pers. comm. M. Zimanowski 2006). Nevertheless, we explored an additional possible zeroing mechanism: hydrostatic pressure, based on the description of "mechanoluminescence" by BANERJEE et al. (1999) (see also Singhvi et al. 1994). The results are published elsewhere (ZÖLLER et al. 2009) and will not be further reported here. It was shown that hydrostatic pressure (1 GPa for $19 \mathrm{~h})$ at room temperature did not significantly reset the natural TL (NTL) of a Lower Devonian slate fragment whereas hydrostatic pressure at elevated temperature $\left(1 \mathrm{GPa}\right.$ at $150^{\circ} \mathrm{C}$ for 19 h) partially reset the NTL beyond the thermal draining. In the following chapters we try to develop a laboratory technique to overcome the problem of partial resetting of maar tephra or crustal xenoliths independent from the question what caused the resetting (heat transfer, frictional heating or hydrostatic pressure).

\section{Samples and sample preparation}

Three kinds of samples were collected for testing TL dating,

a) only slightly consolidated maar tephra-beds,

b) crustal xenoliths extracted from maar tephra or scoria and ash cones, and

c) a piece from Lower Devonian slate (sample no. 5) originating from the same epoch (Upper Siegenium) as country-rock outcropping at Lake Puvermaar (for dose recovery experiments; the sampling locality at the northern end of the Middle Rhine Valley at BonnFriesdorf is far away from possible thermal overprint by Quaternary volcanism).

All samples were processed under subdued red light (diodes, $620 \mathrm{~nm}$ ) after removal of the outer minimum $2 \mathrm{~mm}$ rim using a handsaw. Hard rock samples were carefully crushed in a bench vice and with an agate mortar and sieved. Fine-grain samples were prepared according to ZimMERMAn (1971) and quartz coarse grain samples according to MeJDAhl (1985a) and Aitken (1998). From two samples (13RTL and 14 RTL) fine-grained quartz separates were obtained by etching in $\mathrm{H}_{2} \mathrm{SiF}_{6}$ (Fuchs et al. 2005). More detailed information about the samples is given in Table 1.

\section{Experimental}

TL and IRSL measurements were executed using a Daybreak 1150 TL/IRSL reader equipped with infra-red diodes $(870 \pm 30 \mathrm{~nm})$, an EMI 9586Q photomultiplier (PM) and a combination of four detections filters (BG-3, GG-400, BG-3, BG-39, "blue combination" in Table 1) in front of it. TL readout occurred at a ramp rate 


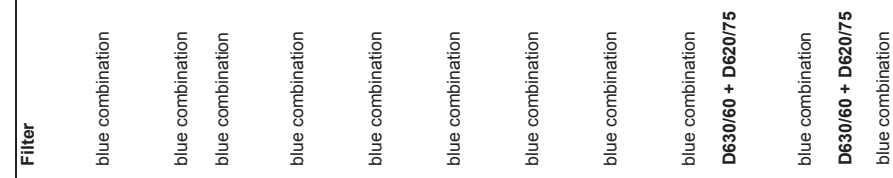

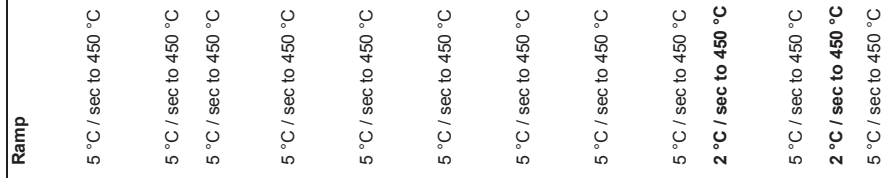

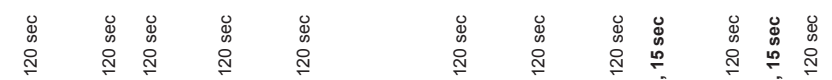

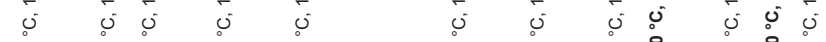

กิ กิ กิ

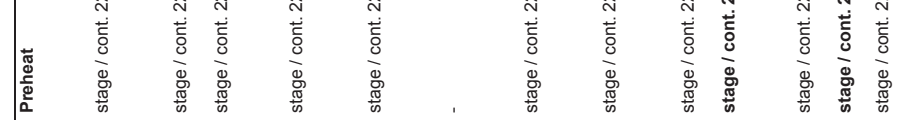

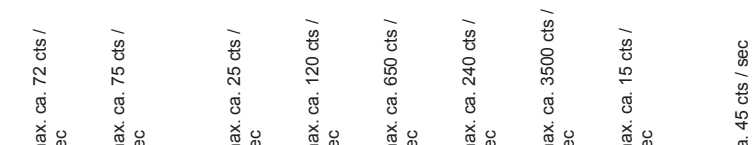

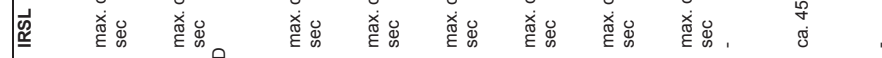

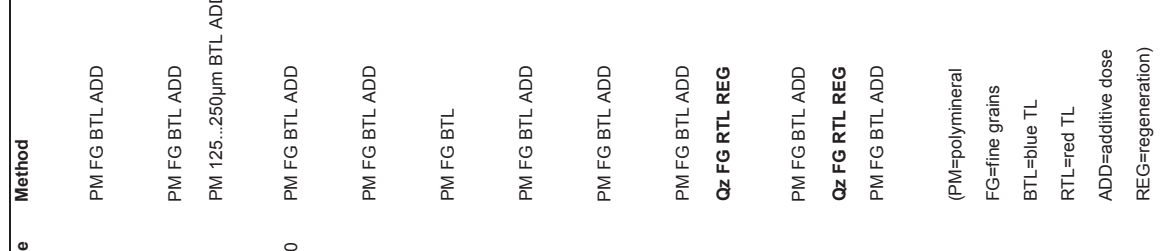

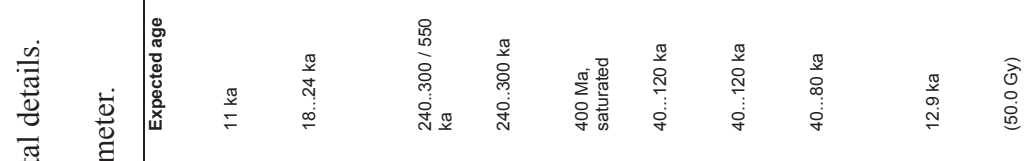

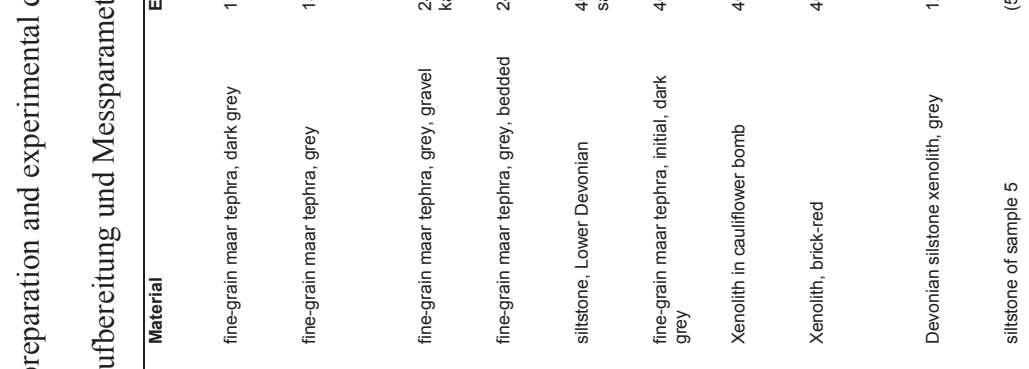

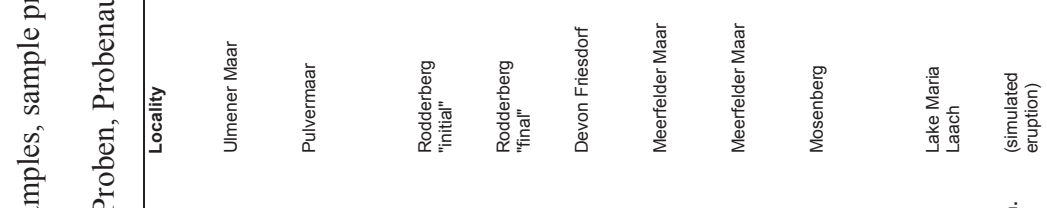

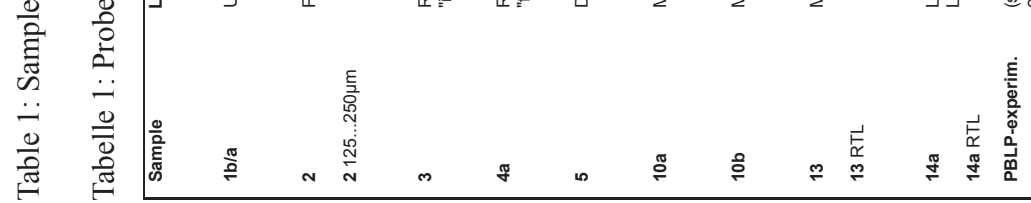


a)

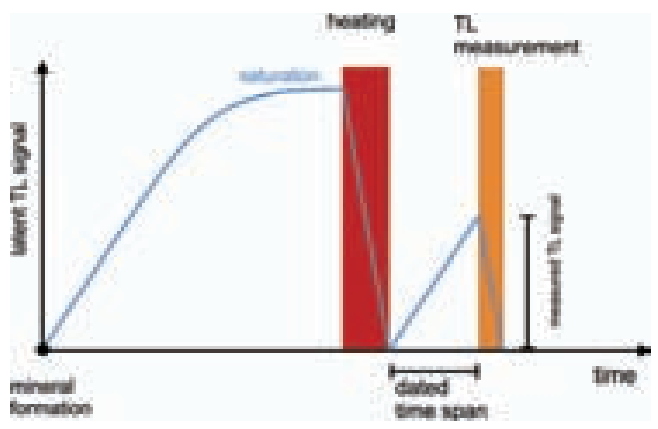

b)

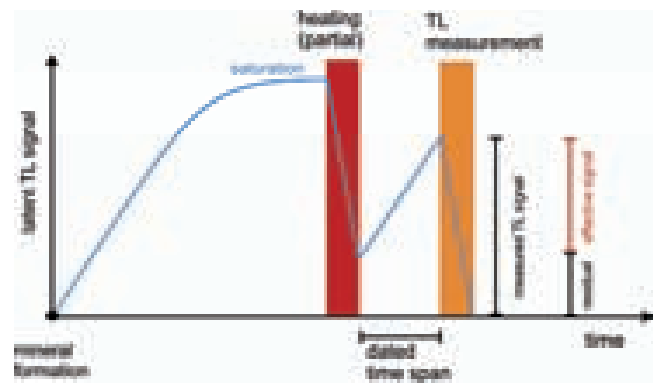

Fig 2: Principles of TL dating assuming total (a) and partial resetting (b) of the parent TL during the event to be dated. The parent TL signal acquired during the geological history of the mineral grain (geological TL) is saturated and then entirely annealed during heating (a). Subsequently, the parent TL signal accumulates again with time due to natural radioactivity of the sample and its environment. The intensity of the natural TL signal (NTL) recorded in the laboratory is a measure of the time elapsed since the last heating. If, however, the heating event did not completely erase the acquired geological TL a residual TL remains at the heating event. The NTL signal measured in the laboratory consists of TL accumulated after the heating event plus an inherited TL signal (b).

Abb. 2: Grundlagen der TL-Datierung unter Annahme vollständiger (a) und partieller Rückstellung (b) des latenten TL-Signals während des datierten Ereignisses. Das latente TL-Signal, welches im Laufe der geologischen Geschichte des Mineralkorns akquiriert wurde, ist in Sättigung und wird dann während der Erhitzung völlig gelöscht (a). Danach wächst das latente TL-Signal wieder infolge der natürlichen Radioaktivität der Probe und ihrer Umgebung. Die Intensität des natürlichen TL-Signals (NTL), welches im Labor gemessen wird, ist ein Maß für die Zeit seit der letzten Erhitzung. Wurde jedoch während des Ereignisses der Erhitzung die akquirierte geologische TL nicht vollständig gelöscht, verblieb ein residuales (ererbtes) TL-Signal. Das im Labor gemessene NTL-Signal setzt sich dann aus dem seit der Erhitzung akquirierten Signal plus dem ererbten Signal zusammen (b).

of $5^{\circ} \mathrm{C}$ (for blue TL) and $2^{\circ} \mathrm{C}$ per second (for orange-red $\mathrm{TL}$, see below), respectively (see Table 1) to a maximum temperature of $450^{\circ} \mathrm{C}$, whereas IRSL was recorded at room temperature. For blue TL preheat of $220^{\circ} \mathrm{C}$ for $2 \mathrm{~min}$ utes was applied ("stage and continue", i. e. the aliquot is heated to $220^{\circ} \mathrm{C}$ and held there for 2 minutes, before heating continues to maximum temperature); deviating protocols for orange-red TL are mentioned in Table 1. For sub-sample 13RTL (Mosenberg volcano) the orange-red TL (RTL) of a pure quartz separate was also measured using a detection filter combination (Oriel D630/60 + D620/75) with transmission from 570 to $685 \mathrm{~nm}$ (maximum from 600-660 nm; based on manufacturer's data). The quantum efficiency of the used PM in this wavelength range is, however, only ca. $1 \%$. Laboratory irradiation was performed using a ${ }^{90} \mathrm{Sr} /{ }^{90} \mathrm{Y}$ beta-source delivering ca. $9.96 \mathrm{~Gy} / \mathrm{min}$.

The age of a sample can - simplified - be calculated as the radiation dose accumulated since the dated event, $D_{E}[\mathrm{~Gy}]$, divided by the effective dose-rate, $\dot{D}[\mathrm{~Gy} / \mathrm{a}]$. To determine the equivalent dose $D_{E}$ it is necessary to define the plateau range, i.e. the glow curve temperature range exhibiting identical $D_{E}$. In case of non-linear dose-response a simple plot of $\mathrm{I}_{(\mathrm{N}+\mathrm{\beta})} / \mathrm{I}_{(\mathrm{N})}$ versus glow temperature (e.g., AitKen 1985, Fig. 1.3), with $\mathrm{I}_{(\mathrm{N}+\mathrm{B})}$ denoting the TL intensity of an additively dosed aliquot and $\mathrm{I}_{(\mathrm{N})}$ the TL intensity of a natural aliquot, respectively, is not justified (e.g., Berger 1991, 1994, Berger \& Anderson 1994). We therefore used the $D_{E}$ plateau test only.

Longer-term anomalous fading tests and corrections (according to AuCLAIR et al. 2003, LA- 
MOTHE et al. 2003) were not yet executed due to limited laboratory time for this pilot study. Instead, an accelerated short term fading test ( 7 days storage at $70^{\circ} \mathrm{C}$ in the oven, see BERGER 1985, 1987, 1988; ZöLLER 1995) was performed on polymineral fine grain samples and apparent equivalent doses were corrected for short term fading: TL intensities of the highest additive dose $\left(\mathrm{N}+\beta_{\text {max }}\right)$ were measured immediately after irradiation and after seven days delay at $70^{\circ} \mathrm{C}$. In case anomalous fading was detected and calculated as

$$
\left[\mathrm{I}_{(\mathrm{N}+\beta \max )}-\mathrm{I}_{\mathrm{N}}\right] /\left[\mathrm{I}_{(\mathrm{N}+\beta \max +\text { delay })}-\mathrm{I}_{\mathrm{N}}\right],
$$

with I = TL-intensity in the ED plateau range, the portion $\mathrm{I}_{(\mathrm{N}+\beta)}-\mathrm{I}_{\mathrm{N}}$ of all additively dosed aliquots was recalculated by subtraction of the fading percentage, and the corrected intensities of $\mathrm{I}_{(\mathrm{N}+\mathrm{B}) \mathrm{i}}$ were used for refitting the additive dose response curve. Although there may be doubts about the general validity of extrapolated long term fading tests this discussion lies outside of the scope of the present study. We are aware, however, that further studies should also include longer-term fading tests. So far, all apparent TL-ages obtained from the polymineral fine grain fraction must be regarded as minimum ages!

Effective internal $\alpha$ - and $\beta$-dose-rates for the dated samples were calculated using thick source alpha-counting of fine-ground bulk samples (Aitken 1985, Zöller \& Pernicka 1989) for $U$ and Th decay chains, and by ICP-MS and AAS measurements for K. Dose conversion factors given by ADAMIEC \& AitKen (1998) were applied. The $\gamma$ dose-rates were calculated from $\mathrm{U}$, Th and $\mathrm{K}$ concentrations of maar tephras if homogeneity for $4 \pi$ geometry could be assumed by field evidence. For xenolith samples not fulfilling the requirements of $4 \pi$ geometry the $\gamma$ dose-rate was measured on-site using a portable $\mathrm{NaI}$ 4-channel gamma spectrometer (Harwell). The very small contribution of cosmic dose-rate was estimated with respect to sample depth below surface using the formula given by PRESCOTT
\& Hutton (1994). The a-value (alpha efficiency, see AitKen 1985) was taken as $0.08 \pm 0.02$ for polymineral fine-grain samples and $0.03 \pm 0.01$ for fine-grain quartz samples. Secular equilibrium of $U$ decay-chains was assumed.

\section{The partial heat - longest plateau (PHLP) technique in TL dating}

\subsection{Partial resetting of parent TL - basic considerations}

Luminescence dating is a paleodosimetric dating method based on the absorption of the energy of ionizing radiation by the sample with time (WAGNER 1998). A basic assumption of luminescence (TL, OSL, IRSL) dating is the complete resetting (zeroing) of the latent luminescence signal at the event to be dated. Heat and light exposure are the most prominent resetting mechanisms allowing the dating of the last heating event of a sample or the last exposure of its mineral grains to daylight (e.g., sedimentation). Incomplete resetting results in an over-estimation of $D_{E}$, and, thus, an age overestimation. It is, therefore, essential to ascertain a complete resetting at the event to be dated or to find applicable corrections for the inherited residual luminescence value (Fig. 2).

For TL dating of sediments with an inherited signal at deposition, MeJdahl (1985b, 1988) presents several so-called "partial bleach" techniques. One of them is called the "longest plateau" technique (MEJDAHL 1988). It relies on the observation that the natural TL of quartz or feldspars consists of components exhibiting different sensitivity to daylight. Assuming that all mineral grains of a sample saw the same light sum prior to deposition, the correct $D_{E}$ can be found if for different glow temperatures within the thermally stable part of the glow-curve the obtained $D_{E}$ s are identical $\left(D_{E}\right.$-plateau). This can be achieved by trying the residual TL of glow-curves from natural TL (NTL) aliquots following various light exposures. Since the advent of optical dating the longest plateau 
technique after MeJDAHL, however, has been more or less abandoned.

When a sample having acquired an amount of NTL is subjected to insufficient (partial) heating (e.g., 200 to $300^{\circ} \mathrm{C}$ ) its $\mathrm{TL}$ is not totally zeroed. Glow peaks lower than or equal to the maximum heating temperature are drained completely, whereas those above the heating temperature are partially erased or even remain unaffected, depending on their peak temperature and the duration of heating. A residual TL glow curve is obtained when the sample is glowed to maximum temperature (450 or 500 ${ }^{\circ} \mathrm{C}$, respectively). The shape of this residual TL glow curve is in some aspects similar to the residual TL after optical bleaching (see Fig. 6b) in so far as the percentage residual TL, referred to the NTL, increases with glow temperature. In contrast to partial optical bleaching, no TL peaks for glow temperatures below the partial heating temperature are recorded. This can

a

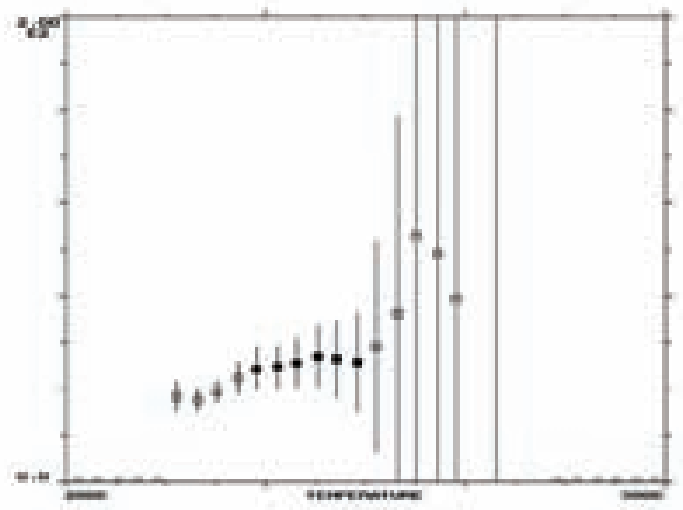

even be considered as an advantage over partial optical bleaching. Thus, MEJDAHL's approach can be modified to the TL dating of partially heated rocks, sediments or soils.

\subsection{A new laboratory protocol for partially heated rocks}

We tried to optimize the longest plateau technique for partially heated volcanogenic material such as crustal xenoliths and maar tephra. We so far developed the following protocol:

1. Construction of a multiple aliquot additive dose-response curve (MAAD). In case a long $D_{E}$ plateau is observed by extrapolation to zero TL level complete resetting of the latent (geological) TL at eruption is proved and the following steps are not necessary (Fig. 2a).

2. A number of zeroed aliquots of the sample to be dated (here: 18 aliquots) are regenerated by a laboratory dose up to the estimated pre-

b

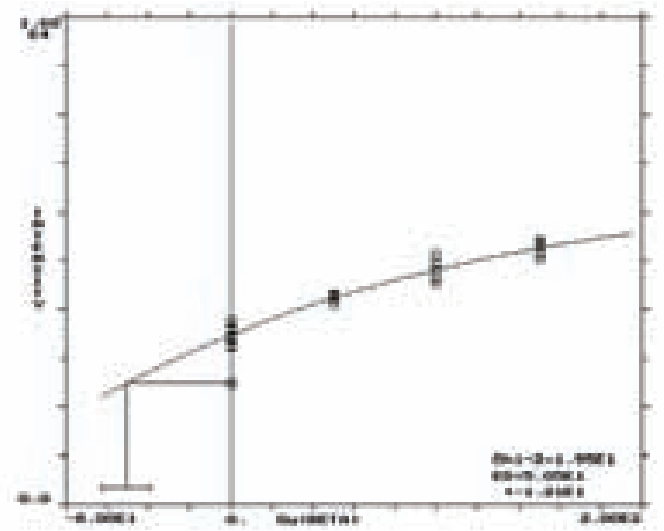

Fig. 3 a: $D_{E}$-plateau of the dose recovery test. The sample 5 with geological TL in saturation was partially heated $\left(15 \mathrm{~min}\right.$ at $\left.300^{\circ} \mathrm{C}\right)$ and then laboratory-dosed with $50 \mathrm{~Gy}$. The PHLP technique recovers a dose of $50.5 \pm 12.1$ Gy (see b).

$\mathrm{b}$ : Results of the PHLP technique applied to sample 5 dosed with 50 Gy after partial heating for 15 min at $300^{\circ} \mathrm{C}$. The PHLP technique recovers a dose of $50.5 \pm 12.1 \mathrm{~Gy}$. The longest $D_{E}$-plateau is seen at the correct equivalent temperature.

Abb. 3a: $D_{E}$-Plateau des Dosis-Wiederherstellungstests. Die Probe 5 mit geologischer TL in Sättigung wurde partiell ausgeheizt $\left(15 \mathrm{~min}\right.$ bei $\left.300^{\circ} \mathrm{C}\right)$ und erhielt dann im Labor eine Dosis von 50 Gy. Die PHLP-Technik findet eine Dosis von 50,5 $\pm 12,1 \mathrm{~Gy}$ wieder (siehe b).

$\mathrm{b}$ : Ergebnisse der PHLP-Technik für Probe 5 mit einer Labordosis von 50 Gy im Anschluss an 15-minütiges partielles Ausheizen bei $300^{\circ} \mathrm{C}$. Die PHLP-Technik findet eine Dosis von 50,5 $\pm 12,1$ Gy wieder. Das längste $D_{E}$-Plateau stellt sich bei der korrekten Äquivalenttemperatur ein. 
Table 2: Summarized TL dating results from three samples of the Rodderberg volcanic complex.

Tabelle 2: Zusammengefasste TL-Datierungsergebnisse von drei Proben des Rodderberg-Vulkankomplexes.

\begin{tabular}{|l|l|l|l|l|l|}
\hline Sample & Material & $\begin{array}{l}\text { Stratigraphic } \\
\text { position }\end{array}$ & $D_{E}(\mathrm{~Gy})$ & $\begin{array}{l}\text { Dose rate } \\
(\mathrm{G} / \mathrm{ka})\end{array}$ & Apparent age (ka) \\
\hline $\mathbf{3}$ & $\begin{array}{l}\text { hydroclastic maar } \\
\text { tephra }\end{array}$ & initial series & $1108 \pm 355$ & $3.70 \pm 0.25$ & $\mathbf{3 0 0} \pm \mathbf{9 8}$ \\
\hline $\mathbf{4 a}$ & $\begin{array}{l}\text { hydroclastic maar } \\
\text { tephra }\end{array}$ & final series & $957 \pm 161$ & $2.87 \pm 0.21$ & $\mathbf{3 3 4} \pm \mathbf{6 1}$ \\
\hline R4-D-1 & slate xenolith & strombolian series & $1403 \pm 141$ & $4.37 \pm 0.24$ & $\mathbf{3 2 1} \pm \mathbf{3 7}$ \\
\hline
\end{tabular}

eruptive dose-level. This step is not used for regenerative dating but only to produce aliquots suited for step 3. In the case of Lower Devonian basement the aliquots must be irradiated up to the saturation dose level (minimum 2,000 Gy; a saturation dose of 2,000 to 5,000 Gy was found for our samples). To minimize irradiator time additive dosing on top of the natural dose is advised.

3. The dosed aliquots are split in 6 groups. The aliquots of each group are subjected to thermal pre-treatment on the hotplate of the TL reader for $5 \mathrm{~min}$ with temperature increments of $10 \mathrm{~K}$. Temperatures for one group each are held at 250, 260, 270, 280, 290 and $300{ }^{\circ} \mathrm{C}$, respectively. By this way, 6 different residual TL levels are produced representing partial annealing of the pre-eruption TL level.

4. Extrapolation of the MAAD dose-response curve (step 1) to the various residual TL levels to obtain the parent $D_{E}$ for each glow temperature in the range from 280 to ca. $400^{\circ} \mathrm{C}$ and for each residual TL level (cf. Figs. 5, 6a). Ideally, the plateau is expected to be the longest if the thermal pre-treatment in the laboratory matches exactly the natural conditions during and after (cooling downperiod) the eruption. This will hardly be the case, and, thus, the laboratory preheat temperature yielding the longest plateau is called "equivalent temperature" (Fig. 2b). Only for an equivalent temperature delivering a residual TL resembling best or very closely the residual TL at eruption an acceptable $D_{E}$-plateau is obtained.

5. Ideally, dating results from two or more xenoliths of the same eruption but yielding different equivalent temperatures and/or dose- rates are identical within error bars and can, thus, validate the eruption age (see section "results").

We designed the following dose recovery experiment to prove the validity of the protocol:

The partial heating of a crustal xenolith during a volcanic eruption was simulated by partial heating of a piece of sample 5 (Lower Devonian basement, TL in saturation) in an oven. To apply a geological "age" to the sample after the artificial "eruption", a defined test-dose of 50.0 Gy was administered in the laboratory following the partial heating.

Detailed protocol of the PHLP dose recovery experiment:

1. Preparation of the polymineral fine grain fraction $(4-11 \mu \mathrm{m})$ from a Lower Devonian basement slate (50 aliquots).

2. Simulation of partial heating during a volcanic eruption by heating the fine grain fraction in an oven at $300^{\circ} \mathrm{C}$ for $15 \mathrm{~min}$.

3. Storage of the aliquots for $>24 \mathrm{~h}$ at room temperature to allow for possible charge redistributions.

4. Additive $\beta$-irradiation (50 Gy) of all aliquots to simulate a geological age of the "eruption".

5. Storage at $160^{\circ} \mathrm{C}$ for $15 \mathrm{~min}$ in an oven to remove thermally unstable TL-peaks, then at room temperature for $>24 \mathrm{~h}$ to allow for charge redistribution.

6. Determination of the apparent $D_{E}$ using the MAAD protocol applying the PHLP technique (Fig. 3 a, b).

7. Using the same fine grain material as produced in the $1^{\text {st }}$ step to produce the residual TL levels after incremental preheat (as de- 

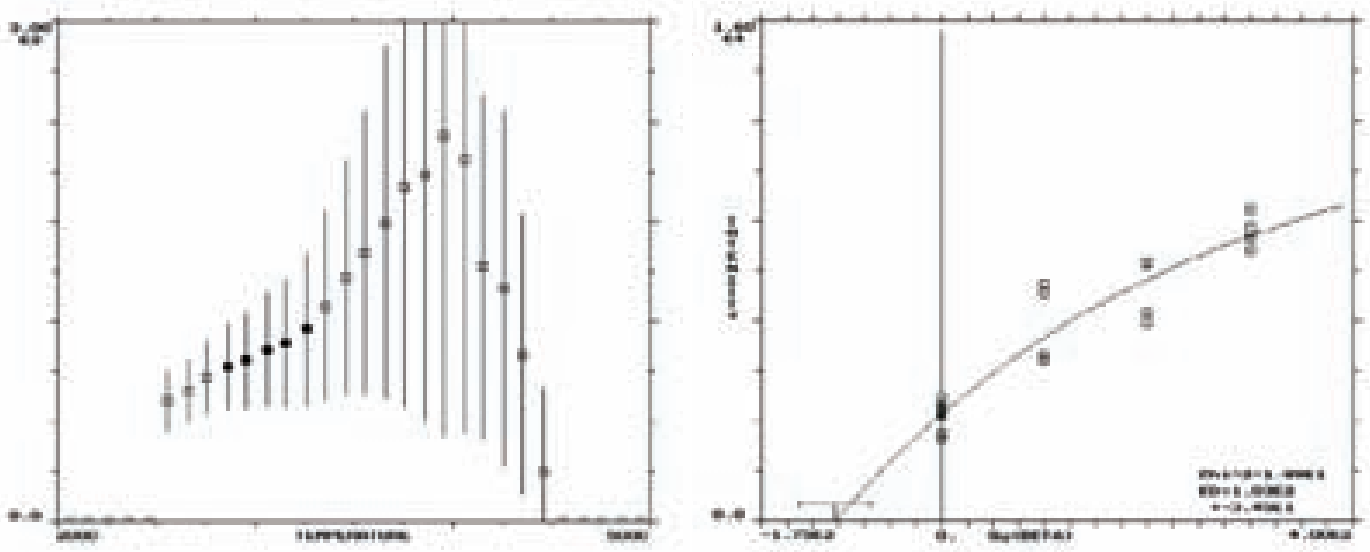

Fig. 4: $D_{E}$-plateau function (top) and dose response curve (bottom) for the $125-250 \mu \mathrm{m}$ fraction of sample 2 (Pulvermaar). A plateau is not obtained if total zeroing of the TL at deposition is assumed. Note that the $D_{E}$ shown in the figure is not corrected for anomalous fading.

Abb. 4: $D_{E}$-Plateaufunktion (oben) und Dosis-Wirkungs-Kurve (unten) für die 125-250 $\mu \mathrm{m}$-Fraktion der Probe 2 (Pulvermaar). Bei Annahme vollständiger Rückstellung der TL bei Ablagerung ergibt sich kein Plateau. Man beachte, dass der $D_{E}$-Wert in der Abbildung nicht um den Betrag des anomalen Ausheilens korrigiert wurde.

scribed above). Laboratory regenerative irradiation up to the pre-eruptive dose-level is not necessary in this case as dose-saturated material without natural thermal overprint is used.

\section{Results}

\subsection{Results of the dose recovery experiment}

By applying the PHLP technique as described above, the artificial laboratory dose was reproduced correctly $(50.5 \pm 12.1$ Gy, see Fig. 3$)$ even if within large error bars. The experiment also confirmed the hypothesis that the extrapolation of the dose response-curve to the correct residual results in a sufficiently long $D_{E}$ plateau, whereas extrapolations to wrong residuals cannot yield a good plateau and result in wrong apparent $D_{E}$ values. The plateau must, however, cover the temperature range of the glow-curve peak relevant for dating to serve as a reliable check for the correct $D_{E}$.

The newly developed PHLP technique can, thus, be expected to reliably date the eruption of partially heated crustal xenoliths. The tech- nique was tested using maar tephra and crustal xenoliths from some Middle and Upper Quaternary eruptions in the West and East Eifel Volcanic Field.

\subsection{Preliminary results from selected volcanic eruptions in the Eifel Volcanic Field}

We first studied maar tephra beds with good to moderate age control to check if the PHLP technique delivers satisfying results for such material. The eruption age of Ulmener Maar (sample 1, Photo 1) is well constrained to ca. 11,000 cal BP by ${ }^{14} \mathrm{C}$-AMS dating and varve chronology (ZoLitschKa et al. 2000). From Pulvermaar (sample 2, Photo 2) a physical dating is not yet available, but from geomorphologic evidence its age is assumed to fall within the last glacial maximum (LGM; LorENZ \& ZIMANOWSKI 2000).

The apparent TL age for Ulmener Maar was calculated to $8.36 \pm 1.11 \mathrm{ka}$ (corrected for short term fading of ca. 13\%). The TL age significantly underestimates the independent age (11 ka, ZoLitschKA et al. 2000), but there is no evi- 

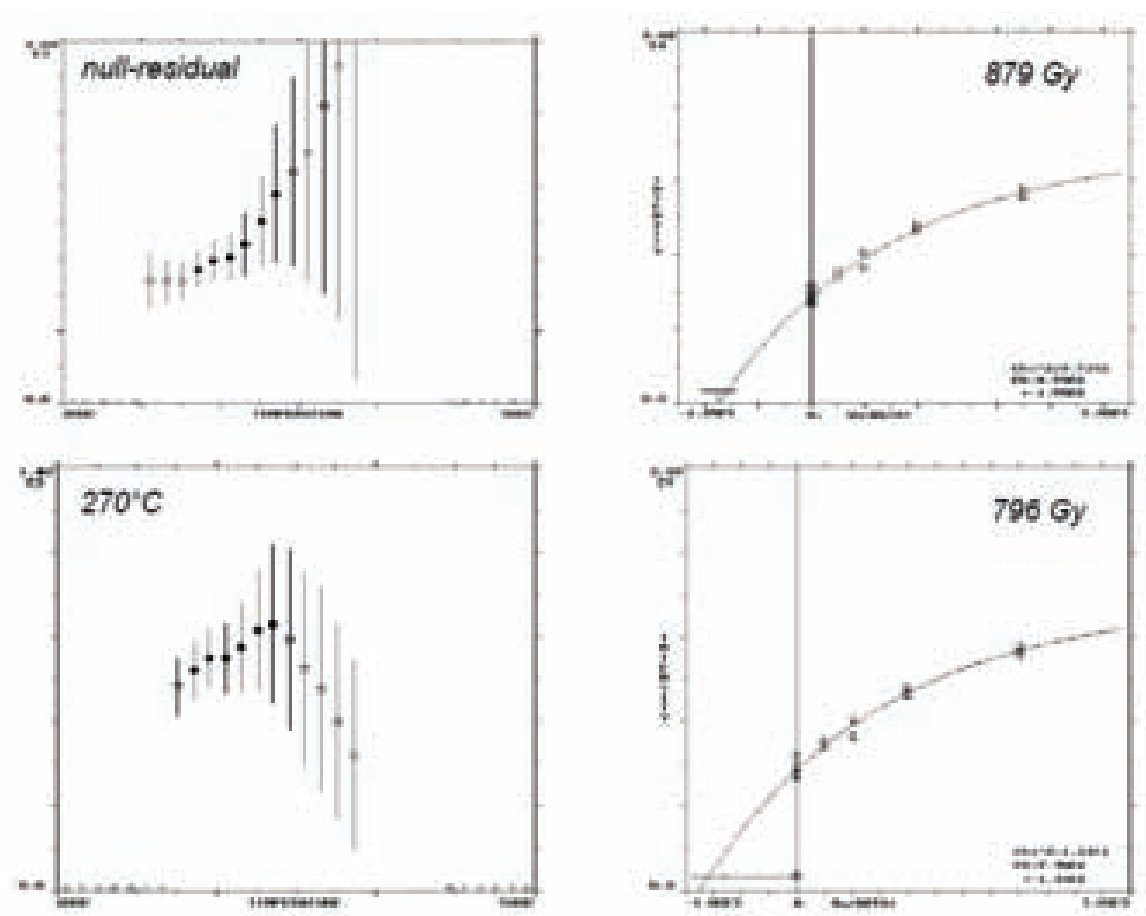

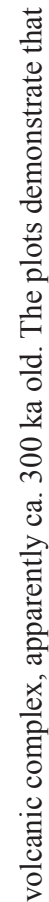
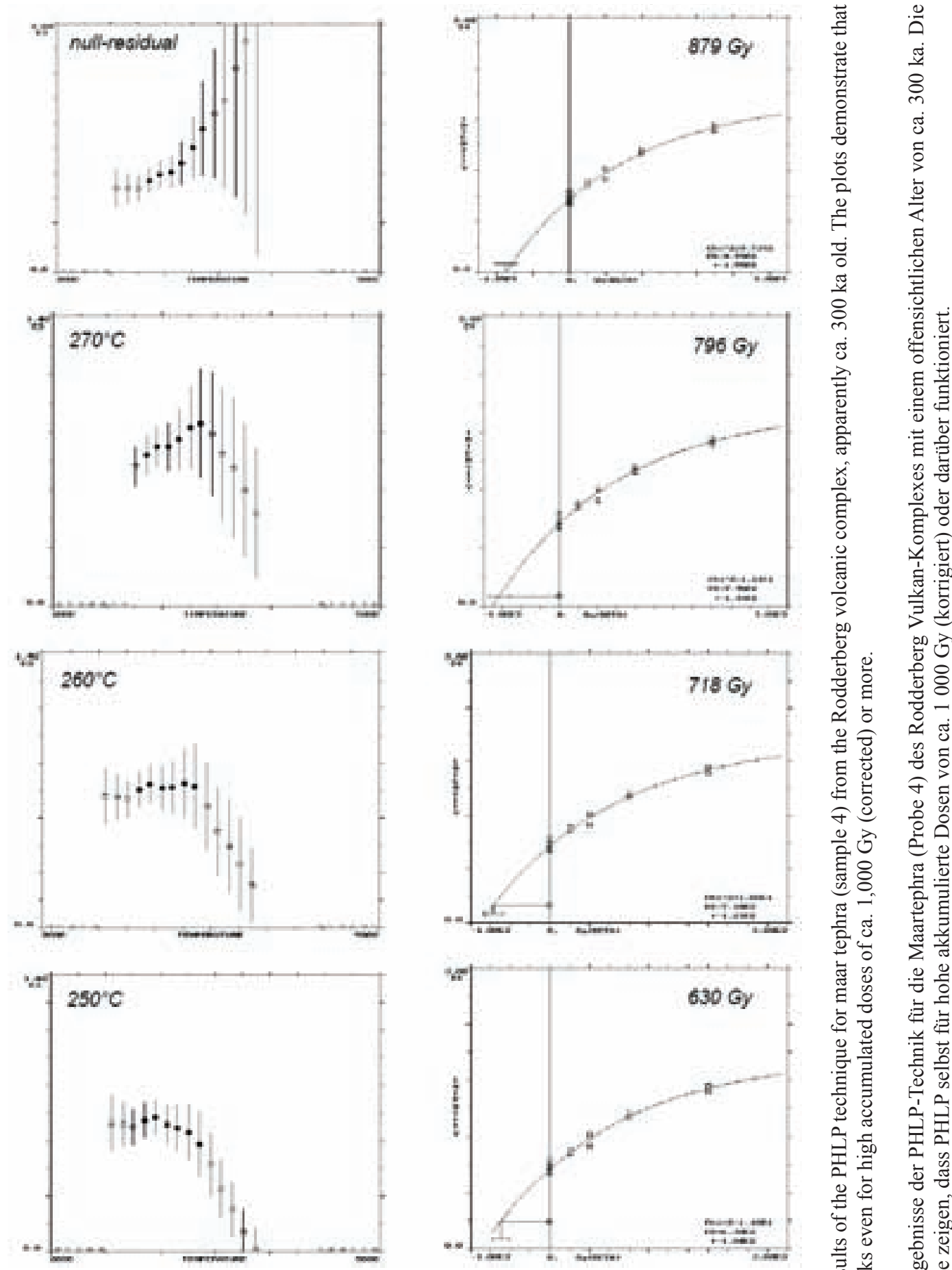

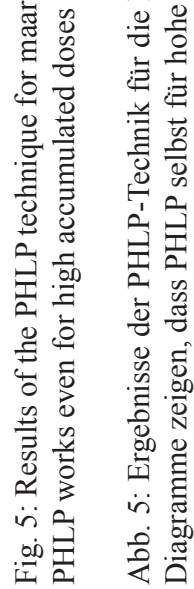


Figure 6 a
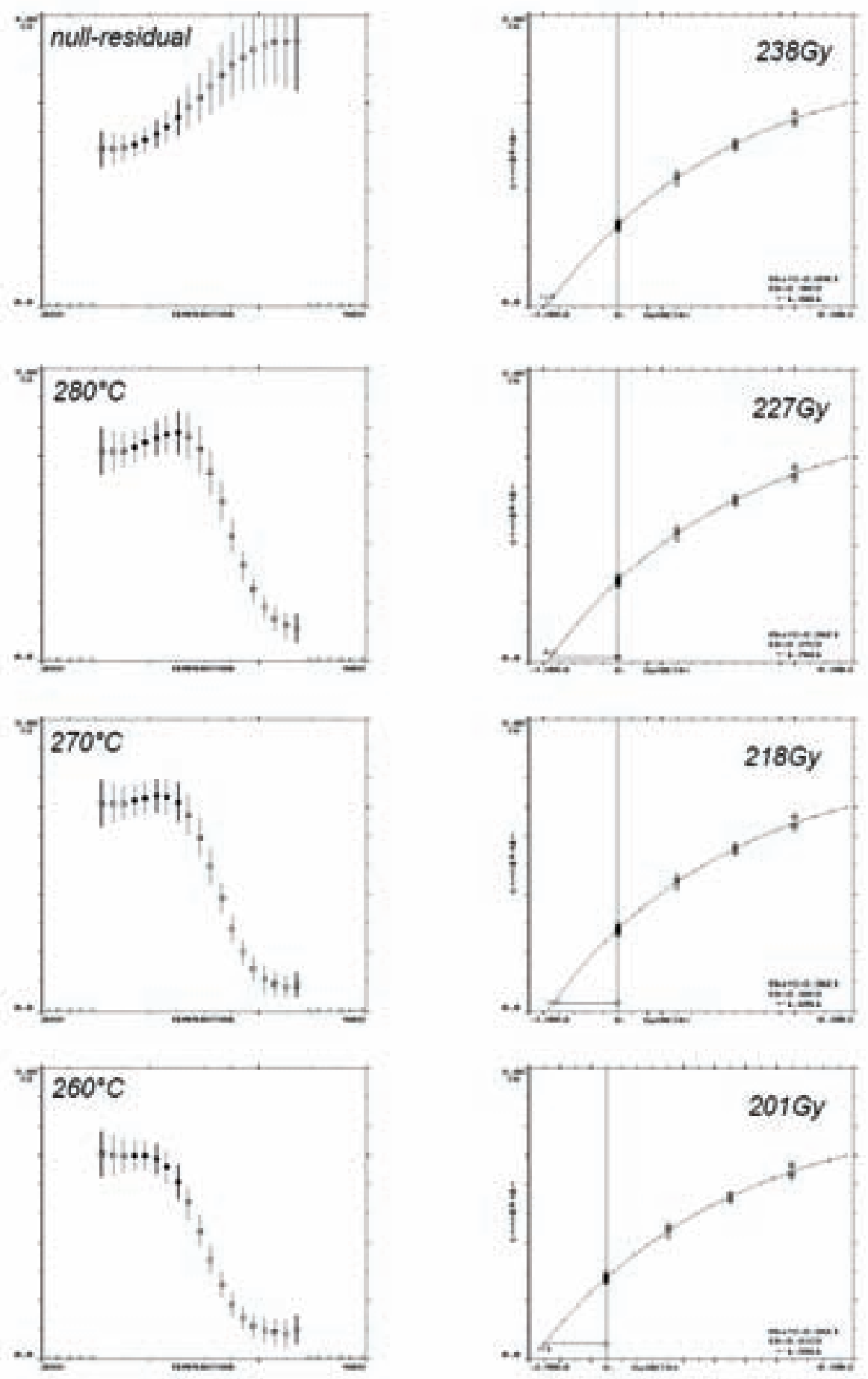
b

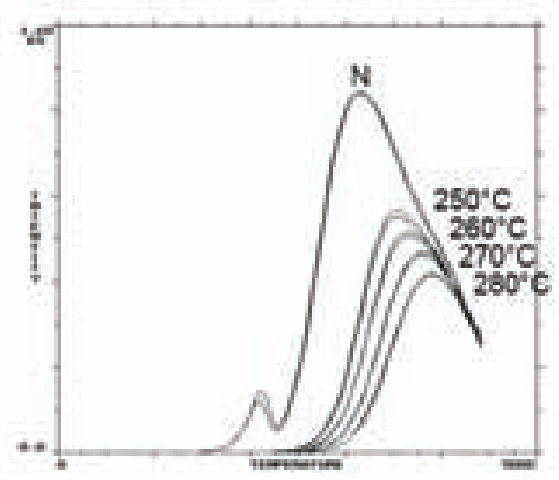

Fig. 6a: Additive dose response curve, residual TL value for $270^{\circ} \mathrm{C}$ equivalent temperature and $D_{E}$ (longest plateau) from sample $10 \mathrm{~b}$ (peperite xenolith from Meerfelder Maar tephra).

b: NTL glow curves and TL residuals after incremental preheat from sample 10b (peperite xenolith from Meerfelder Maar tephra).

Abb. 6a: Additive Dosis-Wirkungs-Kurve, residualer TL-Wert für eine Äquivalenttemperatur von $270^{\circ} \mathrm{C}$ und $D_{E}$ (längstes Plateau) für Probe $10 \mathrm{~b}$ (Peperit-Xenolith aus der Meerfelder Maar-Tephra).

b: NTL-Leuchtkurven und residuale TL nach stufenweisem Vorheizen der Probe 10b (Peperit-Xenolith aus der Meerfelder Maar-Tephra).

dence for age overestimation which would be expected in the case of incomplete TL-zeroing during eruption. The apparent TL age of Pulvermaar $(21.0 \pm 2.95 \mathrm{ka}$, corrected for short term fading of ca. 9\%) lies within the LGM as expected (LorenZ \& ZimanowsKi 2000).

From Pulvermaar we also used the TL of the $125-250 \mu \mathrm{m}$ fractions to check for possible grain size-dependant zeroing. This fraction consists of platy slate clasts. As shown in Fig. 4 (note that data were not corrected for fading) a $D_{E}$-plateau is not obtained using extrapolation of the dose response curve to zero. This suggests that TLzeroing of this fraction during fragmentation in the explosion chamber of the maar was not as complete as for the fine silt fraction.

From the Rodderberg volcanic complex (RVC) south of the city of Bonn, in a previous study one of us (BLANCHARD 2002) dated a wellheated brick-red xenolith (Lower Devonian siltstone) extracted from scoria and obtained an apparent TL-age of $321 \pm 37 \mathrm{ka}$ (sample R4-D1, data in PAulick et al. 2008, Table 2). Tephra from the RVC was found in a nearby loesspaleosol section in loess attributed to the third last glaciation (BARTELS \& HARD 1973, 1974), and the superposition of lapilli tephra and scoria on glacial loess argues for an eruption of the Strombolian series within a cold stage (probably MIS 8, ca. 250 to $310 \mathrm{ka}$ ). PAULICK et al. (2008) support an eruption age of the RVC of ca. $300 \mathrm{ka}$ by geochemical and mineralogical methods and comparison with data given in BogaARd \& Schmincke (1990). For the present study, we sampled two maar tephra beds (sample 3 from the initial maar tephra and sample 4 from the final maar tephra) from the RVC. Both tephra beds are much sandier than the maar tephra beds of samples 1 and 2 .

The Rodderberg maar tephra layers both exhibit evidence of incomplete resetting by partial heating. Equivalent temperatures were found at $270^{\circ} \mathrm{C}$ (sample 3 ) and $260^{\circ} \mathrm{C}$ (sample $4 \mathrm{a}$ ), respectively. Fig. 5 demonstrates that even in the high dose range PHLP yields satisfying results. Short-term anomalous fading was ca. $7 \%$ for sample 3 and ca. $25 \%$ for sample 4 . Effective dose-rates differ significantly (3.70 and 2.87 Gy/ka, respectively), but apparent TL ages are consistent within error bars (Table 2). However, the apparent age of sample 4 in particular must be regarded with caution as the correction for short term anomalous fading may not account for the total amount of fading and related age underestimation. Our results so far argue for a volcanic activity phase of the Rodderberg complex ca. $300 \mathrm{ka}$ ago, but a higher age (e.g., MIS 10) cannot be precluded.

At the base of the rampart of the Meerfelder Maar (West Eifel Volcanic Field) we sampled the initial fine grained maar tephra in the quarry near the village Deudesfeld (sample 10a).

Based on non-consistent radiocarbon ages from organic material, BüCHEL \& LORENZ (1984) interpreted the highest age $(28750+2270-1760$ a BP) as a minimum age of the maar eruption. 
The relatively small amount of preserved maar tephra with respect to the large crater $(1700 \mathrm{~m}$ diameter), and the advanced aggradations of the maar lake argue for a significantly higher age (Negendank, pers. comm., 2006, see also LoRenz \& Zimanowski 2000). Our PHLP TLresults yielded an equivalent temperature of $270^{\circ} \mathrm{C}$. Short-term anomalous fading was ca. $10 \%$. The apparent TL (minimum) age is $69.2 \pm 14.5 \mathrm{ka}$.

Our further studies concerned crustal xenoliths to verify the PHLP technique for material which was exposed to partial or even total zeroing of its parent TL. In the tephra originating from Meerfelder Maar some basaltic bombs containing peridotite (up to $20 \mathrm{~cm}$ diameter), pyroxene xenocrystals and light greyish "peperite" (LORENZ \& ZiMANOWSKI 2000) with fragments of hydroclastic country rock occur. The latter bombs are also known as "cauliflower bombs". A peperite extracted from a cauliflower bomb was dated (sample 10b) using the PHLP technique. The equivalent temperature was found at $270^{\circ} \mathrm{C}$ (Fig. 6 a). Natural TL glow curves and residuals after incremental preheat are shown in Fig. 6 b. Short term anomalous fading was ca. 5\%. The apparent TL age of $80.4 \pm 8.34 \mathrm{ka}$ is consistent with the apparent age of sample 10 a within error bars despite significantly different effective dose-rates $(2.85 \mathrm{~Gy} / \mathrm{ka}$ and 4.54 Gy/ka, respectively). Our results thus confirm the much higher age of the maar eruption than previously thought: the eruption and, thus, the preserved paleovegetation remnants correlate to the Odderade interstadial (or an even older warm phase) rather than the Denekamp interstadial (BüCHEL \& LORENZ 1984).

Another crustal xenolith (Lower Devonian brick-red siltstone, sample 13) was extracted from the Mosenberg scoria cone from an exposure at the southwest foot of the volcanic hill. The Mosenberg volcanic complex (MVC) consists of several scoria cones and maars lying on a SE-NW oriented fault line. The nearby Meerfelder Maar is also believed to belong to this $3 \mathrm{~km}$ long volcanic complex with altogether seven eruptive centres ( 5 scoria cones and 2 maars) and 4 lava flows. It is believed so far that volcanic activity shifted from $\mathrm{SE}$ to $\mathrm{NW}$ (LoRenz \& Zimanowski 2000). Based on radiocarbon dating results from Meerfelder Maar and another radiocarbon age from Hinkelsmaar at the north-western end of the MVC (Juvigné et al. 1988), the minimum age of the complex is ca. 29 ka BP, but Lorenz \& Zimanowski (2000) estimate it to be considerably older. ZÖLLER (1989) obtained a TL age of $42 \pm 3 \mathrm{ka}$ from a brick-red slate xenolith found in the exposure mentioned above, but WoDA (2000) dated $87 \pm 8$ ka using ESR of a heated quartz pebble, and from volcanic glass LEYK \& LIPPOLDT (1997) report a ${ }^{40} \mathrm{Ar} /{ }^{39} \mathrm{Ar}$ age of $81 \pm 23 \mathrm{ka}$, which is not documented in detail, however. It is possible that the TL age by ZöLLER (1989) dates a younger eruption, but undetected long-term

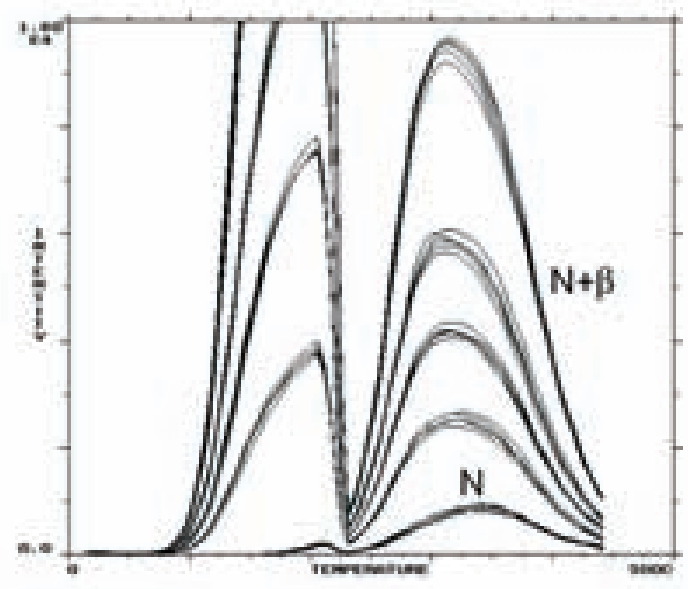

Fig. 7: TL glow-curves from natural and additively dosed aliquots of sample 13 (brick-red slate Xenolith from the Mosenberg scoria cone) after preheating at $220^{\circ} \mathrm{C}$ for $2 \mathrm{~min}$. The peak-shift towards lower glow temperatures of remaining glow peaks $\left(>220^{\circ} \mathrm{C}\right)$, referred to the NTL peak, indicates metastable TL of additively dosed aliquots still present after preheat.

Abb. 7: TL-Leuchtkurven natürlicher und additiv bestrahlter Teilproben der Probe 13 (ziegelroter Schiefer-Xenolith aus dem Mosenberg-Schlackenkegel) nach 2-minütigem Vorheizen bei $220^{\circ} \mathrm{C}$. Die im Vergleich zur NTL sichtbare Verschiebung des Maximums $\left(>220^{\circ} \mathrm{C}\right)$ additiv bestrahlter Teilproben nach Vorheizen zu niedrigeren Leuchtkurven-Temperaturen spricht für metastabile TL dieser Teilproben, die auch nach dem Vorheizen noch präsent ist. 
anomalous fading may also account for the younger TL age.

The polymineral fine grain fraction of sample 13 was first measured using blue TL emissions. A long $D_{E}$ plateau indicates that the xenolith was well heated. As was also found by ZöLLER (1989), the dose response shows a linear growth up to high additive doses (1,000 Gy) and no detectable short-term anomalous fading. The apparent TL age is, however, only $27.0 \pm 2.66$ $\mathrm{ka}$, which is supposed to be due to metastable components of the laboratory induced TL as indicated by a peak shift towards lower glow temperatures after a preheat of $220^{\circ} \mathrm{C}$ for $2 \mathrm{~min}$ (Fig. 7), whereas ZöLler (1989) preheated at $270^{\circ} \mathrm{C}$ for $1 \mathrm{~min}$. Because of the metastable components the apparent TL-age of 27.0 \pm 2.66 $\mathrm{ka}$ is discarded.

We then extracted pure fine grain quartz separates by etching in $\mathrm{H}_{2} \mathrm{SiF}_{6}$ and measured the orange-red TL (sample 13RTL, 600-660 nm) using a regeneration protocol. Aliquot to aliquot reproducibility is substantially better than for blue TL. Anomalous fading has so far not been reported for the red TL (RTL) of quartz. RTL glow curves correspond to the shape described, e.g., by Fattahi \& Stokes (2003) peaking at $330^{\circ} \mathrm{C}$, and the $D_{E}$-plateau ranges from 300 to $360^{\circ} \mathrm{C}$. The apparent age rises to $53.1 \pm 1.83 \mathrm{ka}$. The pronounced supra-linearity of the regenerated dose response-curve (Fig. 8) may, however, may indicate TL sensitivity change due to heating which was not expected according to previous RTL dating studies from burnt flint (RICHTER \& KRBETSCHEK 2006). We therefore regard this RTL age with caution until further studies can prove the reliability of the applied regeneration protocol. Nevertheless, the apparent RTL age supports the evidence for metastable blue TL components from polymineral fine grains of the sample.

From the well-dated (12.9 ka) trachytic Lake Maria Laach tephra a whitish crustal xenolith (quartzite?) was sampled at the famous "Wingertsberg" site (SCHMINCKe 2000). The polymineral fine grain (sample 14a) and the quartz fine grain fraction (14RTL, regeneration) were prepared, whereas a quartz coarse grains dat- ing failed because of too small sample amount. The blue TL of sample $14 \mathrm{a}$ showed a long $D_{E^{-}}$ plateau from 310 to $380^{\circ} \mathrm{C}$, but the apparent TL age $(7.09 \pm 1.34 \mathrm{ka})$ significantly underestimates the known age. Short-term anomalous fading could not be reliably determined due to very low signal to noise ratio, but anomalous fading is assumed to account for the age underestimation. An inhomogeneous natural radiation field of the xenolith and the surrounding trachytic pumice may also account for overestimation of the effective dose-rate. If anomalous fading can be corrected for or avoided by using RTL, equivalent xenolith samples should be datable by TL as heating during eruption appeared sufficient. RTL intensities of 14RTL were, unfortunately, very low, but the RTL $\left(330-360^{\circ} \mathrm{C}\right)$ around the peak temperature suggests an apparent age of $10.8 \pm 0.63 \mathrm{ka}$ (linear fit) and $10.4 \pm 0.72 \mathrm{ka}$ (exponential fit), respectively. The RTL regenerated after TL readout of the natural N-RTL does not start, however, at

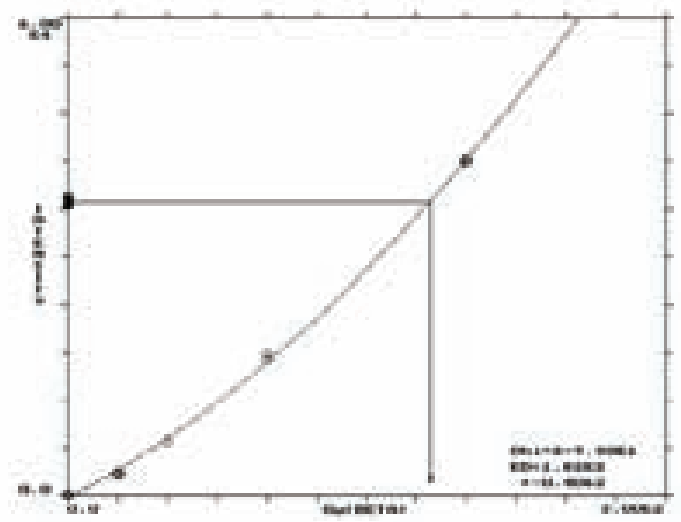

Fig. 8: Natural TL (600-660 nm emissions) of finegrained quartz from sample 13RTL (brick-red slate Xenolith from the Mosenberg scoria cone) and regenerated dose response curve (quadratic curve fitting). Note the pronounced supralinearity of the regenerated RTL.

Abb. 8: Natürliche TL (600-660 nm-Emission) von feinkörnigem Quarz der Probe 13RTL (ziegelroter Schiefer-Xenolith aus dem Mosenberg-Schlackenkegel) und regenerierte Dosis-Wirkungs-Kurve (quadratische Kurvenanpassung). Man beachte die ausgeprägte Supralinearität der regenerierten RTL. 


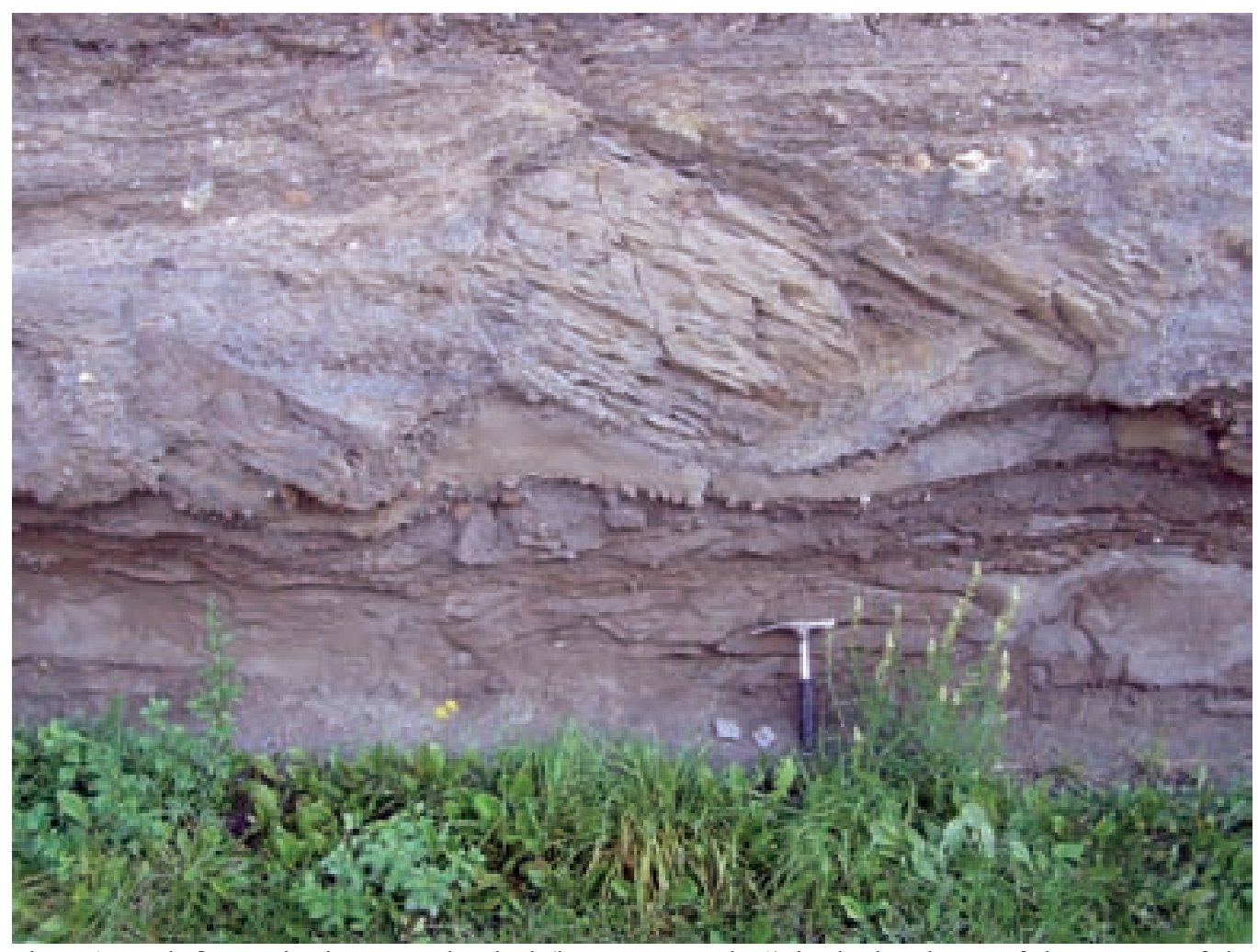

Photo 1: Dark fine-grained maar tephra bed (hammer, sample 1) in the basal part of the rampart of the Ulmener Maar, topped by a diaclastic base-surge layer.

Foto 1: Dunkle feinkörnige Maartephra (Hammer, Probe 1) im basalen Teil des Tuffrings des Ulmener Maars, überlagert von diaklastischen Ablagerungen eines pyroklastischen Stromes („Base surge“).

zero for zero dose. It appears that some kind of recuperation has occurred after the first N-RTL readout which may also lead to an underestimate of $D_{E}$. Furthermore, the "through form" of the $D_{E}$-plateau may argue for TL sensitivity change after the first glow as the regenerated RTL peak exhibits a smaller half-width than the natural glow peak.

\section{Discussion}

The observed total or partial resetting of TL glow peaks in maar tephra and xenoliths derived from non-volcanic country rock may have several reasons:

a) merely thermal bleaching (questionable but not to be excluded for hydroclastically fragmentised rocks), b) thermodynamic fragmentation by dynamic pressure (frictional heating), and

c) hydrostatic high pressure at elevated temperatures (ZöLLER et al. 2009).

Mere thermal resetting of the TL during or prior to maar eruption due to heat transfer from the rising magma into the adjacent non-volcanic rock is expected to affect all rock clasts. Our results, however, found evidence for grain sizedependent resetting in maar tephra, arguing for a resetting by frictional heating or thermally assisted hydrostatic pressure, or both, rather than merely thermal resetting by heat transfer.

For crustal xenoliths, these two resetting mechanisms are unlikely and thermal resetting (heat transfer) is probably the most effective resetting mechanism. As rocks - in particular dry rocks - are poor heat-conductors, long-lasting 


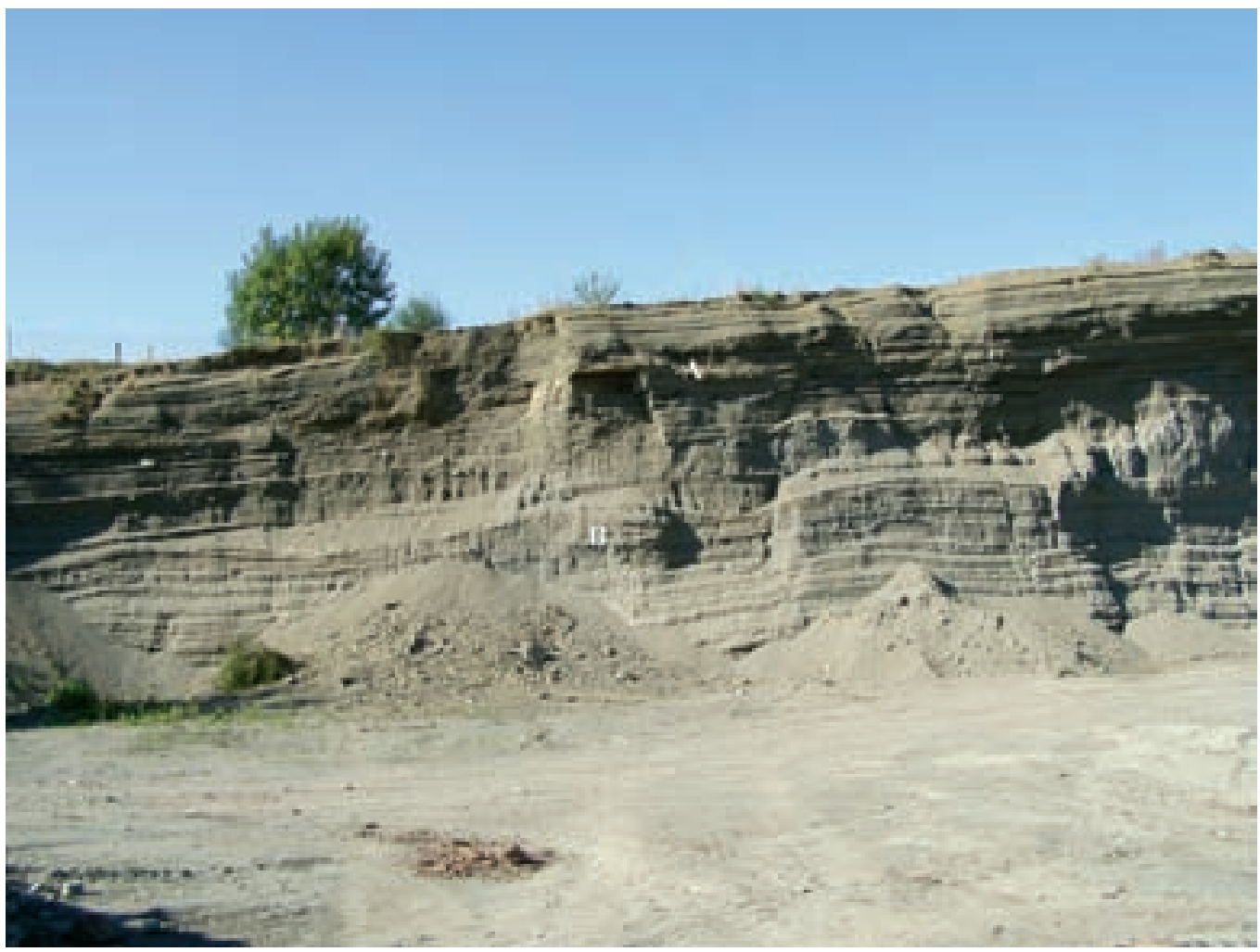

Photo 2: Exposure in the rampart of the Pulvermaar. The light fine-grained bed (sample 2) is visible in the upper third of the exposure (A). In the lower part antidunes and "swimming blocks" witness base surge deposition (B). In former years an ice-wedge cast was exposed in the uppermost part of the tephra, indicating harsh permafrost climate after the deposition of the rampart. The height of the exposure is 10 to $11 \mathrm{~m}$.

Foto 2: Aufschluss im Tuffring des Pulvermaares. Die helle feinkörnige Lage (Probe 2) ist im oberen Drittel des Aufschlusses sichtbar (A). Im unteren Teil belegen Antidünen und „schwimmende Blöcke“ einen pyroklastischen Strom („Base surge“-Ablagerung) (B). In früheren Jahren war eine Eiskeil-Pseudomorphose im obersten Teil der Tephra aufgeschlossen, die raues Dauerfrostboden-Klima nach der Ablagerung des Tuffrings belegt. Die Höhe des Aufschlusses beträgt 10-11 m.

heating of the xenolith can be expected to be a prerequisite for total TL-resetting within the xenolith. Brick-red slate and siltstone xenoliths as well as light greyish to whitish altered xenoliths which experienced even higher temperatures appear to be suited for TL dating of their eruption. However, in the case of fast cooling of volcanic products as may be expected for volcanic bombs and for scoria falls, the heating time may not have been sufficient to generate a homogenous heat profile within a xenolith originating from a shallow depth $(<1-3 \mathrm{~km})$. For microdosimetry reasons (ranges and geo- metry of $\alpha-, \beta-$, and $\gamma$ radiation), probing the inner parts of a xenolith is desirable. The new PHLP technique proves its ability to overcome problems related to incomplete heating and related residual TL at the eruption. Our dating attempts using the PHLP technique so far demonstrate that its capability to date volcanic events is independent of the resetting mechanism.

Although one of the motivations to use crustal xenoliths for dating volcanic events was to circumvent the strong anomalous fading known from volcanic feldspars and other volcanic 
minerals, anomalous fading still raises a major problem. Some samples not exhibiting shortterm anomalous fading clearly underestimate the known age; whereas others with even strong (up to $25 \%$ ) short term anomalous fading, after 7 days storage at $70^{\circ} \mathrm{C}$ allowing for settling of the fast component of the fading process, yield apparent TL ages in agreement with independent age estimates. This could be demonstrated, e.g., for our oldest dated samples from the Rodderberg volcanic complex, apparently ca. $300 \mathrm{ka}$ old. The Rodderberg samples furthermore prove the applicability of the PHLP technique to Middle Pleistocene eruptions at least up to this age.

Our dating results from Rodderberg and from Meerfelder Maar - apart from the pending fading problem - support the overall validity of our TL dating protocols as different materials (maar tephra, crustal xenoliths) yield identical apparent TL ages within error bars. From volcanic events with well-based known age no significant age overestimates are obtained: the Rodderberg volcanic complex must be younger than ca. $500 \mathrm{ka}$ as the complex rests on a River Rhine terrace $\left(t_{R 6}\right)$ supposed to be ca. $500 \mathrm{ka}$ old $\left(6^{\text {th }}\right.$-to-the-last glacial, see BIBus 1980). Apparent TL ages from Lake Maria Laach tephra and Ulmener Maar tephra underestimate the known ages, most probably due to long-term anomalous fading (see above). Our apparent age from the Pulvermaar supports the geomorphologically based age estimate (LGM), but other sound age information is not available so far. Our age estimates from the Meerfelder Maar corroborate the geomorphologically much higher age estimate than suggested from radiocarbon minimum ages. The age obtained from the slate xenolith extracted from the Mosenberg scoria cone using blue TL is rejected due to metastable TL signals (see above), whereas the apparent RTL age (quartz fine grain fraction) from the same xenolith is closer to the ESR and ${ }^{40} \mathrm{Ar} /{ }^{39} \mathrm{Ar}$ age estimates of the underlying lava flow. If it holds true that the MVC including Meerfelder Maar erupted within a short time period as suggested by previous authors (see review by LORENZ \& ZI-
MANOWSKI 2000) the entire complex could have been formed some $80 \mathrm{ka}$ ago, but rejuvenated activity of the Mosenberg volcano cannot be precluded at present.

As maar lakes are most valuable geoarchives often containing long records of annually varved sediments (ZoLitschKa et al. 2000, NEGENDANK \& ZoLITSCHKA 1993), reliable dating of maar eruptions serves as an essential tool to envisage the maximum time span covered by those high resolution geoarchives (see also SiROcKo et al. 2005). Reliable dating of alternating volcanic activity phases in the two spatially distinct Eifel Volcanic Fields (and other Central European areas with Quaternary volcanic activities) will also be crucial to validate the model of pulsed fingers of the "Eifel Plume" as presented by RITTER el al. (2001) and to further investigate its dynamics during the Middle and Upper Pleistocene. For the past 200 to $300 \mathrm{ka}$, in particular, TL dating using the PHLP technique can prove very valuable and complementary to fill dating gaps, as $\mathrm{K} / \mathrm{Ar}$ or ${ }^{40} \mathrm{Ar} /{ }^{39} \mathrm{Ar}$ dating is difficult if sanidines are lacking and radiocarbon dating is hampered by the lack of suitable datable material or its limited time range.

\section{Conclusions and Outlook}

High hydrostatic pressure and elevated temperatures (but too low for total annealing of the geological TL) may occur at shallow crustal depths $(<2 \mathrm{~km})$ in the root zone of hydroclastic maar eruptions during the fragmentation phase just prior to the opening of the maar eruption vent. This may cause partial resetting of the latent TL (and IRSL) in addition to heat transfer from the rising magma to neighbouring country rock and to frictional heating (TAKEUCHI et al. 2006). Recognizing and estimating the amount of partial resetting is essential to correctly date volcanic eruptions by luminescence and to circumvent age overestimates.

We demonstrated that the PHLP technique of TL dating applied to maar tephra or crustal xenoliths is suited to obtain meaningful eruption ages back to a minimum of $300 \mathrm{ka}$. The PLHP technique involves an intrinsic check 
for incomplete resetting of the latent TL signal at eruption and determination of the inherited natural TL intensity. Thus, overestimates of TL eruption ages are avoided. Age underestimates attributed to long-term anomalous fading were rather observed from some samples of knownage eruptions. For this reason apparent TL ages presented in this study have to be regarded as minimum ages. Circumventing or correcting for anomalous fading as a limiting factor for reliable TL dating remains a challenge, even if volcanic feldspars (and other volcanic minerals) may be more prone to anomalous fading than mainly non-volcanic minerals or mineral assemblages from maar tephra and crustal xenoliths used in our experiments. As this pilot study was designed to develop and test the PHLP technique rather than to produce definite ages and as laboratory time was limited, long-term fading tests following AuClAIR et al. (2003) have not been executed so far, but will be a major aim of further studies. Instead, an accelerated test for short-term anomalous fading after BERGER (1987) was applied for correction of equivalent doses, but correction factors and, thus, correct equivalent doses may still be underestimated. Our data give some evidence, however, that short-term anomalous fading observable in the laboratory and mid- or longterm anomalous fading sensu XIE \& AitKeN (1991) not directly observable may be different and non-proportional processes (see also ZöLlER 1995, for TL ages from loess). In this case, even longer observation of anomalous fading in the laboratory may not necessarily result in correct ages.

Therefore, other strategies to circumvent anomalous fading should be designed. One approach which has already been tested successfully (see review by FATTAHI \& StOKes 2003) is the use of orange-red TL (RTL) emissions from quartz. It remains to be investigated, however, if the PHLP technique is applicable to the RTL from quartz. This may be even doubted as the RTL glow peak used for dating normally is symmetric and has a much smaller half-width than the blue TL (BTL) from quartz and feldspars in the relevant glow temperature range.
Nevertheless, RTL-PHLP measurements on samples for which partial resetting were detected by BTL-PHLP is required in future studies. Another problem with RTL from quartz, the pronounced supralinerarity of the (regenerated) dose-response curve observed from our sample 13RTL, needs further systematic investigations. In general, further investigations into the reliability of the regeneration method for RTL appear inevitable as TL sensitivity change after the first TL-readout may turn out to be a more significant problem than for the RTL of burnt flint (Richter \& KRBEtscheK 2006). The still significant RTL age-underestimate of our sample 14RTL may underline this problem.

Isothermal decay of TL (JAIN et al. 2005) at temperatures below or equal to the temperature experienced by the sample during eruption may be considered as an alternative as well. One problem with application to partially heated rocks will be to anneal thermally unstable laboratory-induced TL (dose-rate of laboratory irradiation is up to ca. $10^{9}$-fold of the natural doserate) in a way equivalent to the annealing of naturally induced TL at ambient temperatures. ZÖLLER \& WAGNER (1989) report experiments using the "partial thermal washing technique" (preheat only applied to laboratory dosed subsamples) for TL-dating of loess which demonstrate that exact matching of the glow peaks is rarely achieved. Alternatively, "plateau heating" as established for fission track dating to isolate thermally stable track lengths from both natural and induced fission tracks (WESTGATE 1988, WAGNER 1998) could be applied prior to isothermal TL, but the necessary annealing temperatures may be as high as or even higher than equivalent temperatures during eruption and erase most or all of the TL signal relevant for dating. The dating approach using isothermal TL of partially heated materials may therefore not look very promising; nevertheless it deserves experimental testing. Anomalous fading of polymineral samples is expected to raise similar problems as with the PHLP technique. Another "partial bleach"-technique originally developed for TL dating of sediments (WINTLE \& HuntLey 1980) called R- $\beta$ or R- $\gamma$ technique 
(see also Aitken 1985, Berger 1988, Zöller 1995), may be adopted and tested for TL dating of partially heated rocks as well. Similar as for partial optical bleaching of the TL of sediments, the ratio of resetting during partial heating referred to the natural TL is glow temperature-dependent. By replacing laboratory optical bleaching using incremental bleach times with laboratory partial heating using incremental temperatures as shown for the PHLP technique, the correct $D_{E}$ accumulated since the eruption may be expected. This technique anticipated here may be preliminarily called "PHR- $\beta$ " technique. The validity of this approach has, however, to be tested in laboratory experiments which, to our knowledge, have not been tried so far.

The present study may open new perspectives for TL dating of Middle and Upper Quaternary volcanic events by the evolution of a complementary physics-based dating method applicable to a wide range of materials and eruption types. Although TL dating of heated materials has by now been employed since almost 50 years (see GröGLER et al. 1960) we stand at the beginning of dating partially heated volcanogenic eruptives, and more fundamental research may be stimulated by this contribution.

\section{Acknowledgements}

The present pilot study was sponsored by the Deutsche Forschungsgemeinschaft (German Research Foundation) DFG, project number Zo 51/28-1. We thank Dipl-Inf. (FH) Manfred Fischer for support during laboratory work in the luminescence dating laboratory at the University of Bayreuth, Dr. Catherine McCammon (BGI, Bayreuth) for improving the English of our manuscript, and PD Dr. Daniel Richter (MPI for Evolutionary Anthropology Leipzig) for critical and helpful reviewing.

\section{References}

Adamiec, G., \& Aitken, M. J. (1998): Dose-rate conversion factors: update. - Ancient TL, 16: 37-50.
AitKen, M. J. (1985): Thermoluminescence dating. 359 S.; London (Academic Press).

Aitken, M.J. (1998): An Introduction to Optical Dating. - 267 S.; Oxford (Oxford Univiversity Press).

Auclair, M., Lamothe, M. \& Huot, S. (2003): Measurement of anomalous fading for feldspar IRSL using SAR. - Radiation Measurements, 37: 487492.

Banerjee, D., Singhvi, A.K., Pande, K., Gogte, V.D. \& ChANDRA, B.P. (1999): Towards a direct dating of fault gouges using luminescence dating techniques - methodological aspects. - Current Science, 77/2: 256.

Bartels, G. \& Hard, G. (1973): Rodderbergtuff im Rheinischen Quartärprofil. Zur zeitlichen Stellung des Rodderberg-Vulkanismus. - Catena, 1: 31-56.

Bartels, G. \& Hard, G. (1974): Zur Datierung des Rodderbergs bei Bonn. - Decheniana, 126 (1973/1974): 367-376.

Berger, G.W. (1985): Thermoluminescence Dating of Volcanic Ash. - Journal of Volcanology and Geothermal Research, 25: 333-347.

Berger, G.W. (1987): Thermoluminescence dating of the Pleistocene Old Crow tephra and adjacent loess, near Fairbanks, Alaska. - Canadian Journal of Earth Sciences, 24: 1975-1984.

Berger, G.W. (1988): Dating Quaternary events by luminescence. - In: EASTERBRoOK, D.J. (ed.): Dating Quaternary Sediments. - Geological Society America Special Paper, 227: 13-50.

Berger, G.W. (1991): The use of glass for dating volcanic ash by thermoluminescence. - Geophysical Research, 96: 19705-19720.

Berger, G.W. (1994): Thermoluminescence dating of sediments older than about $100 \mathrm{ka}$. - Quaternary Science Reviews, 13: 445-455.

Berger, G.W. \& Anderson, P.M. (1994): Thermoluminescence dating of an Arctic lake core from Alaska. - Quaternary Science Reviews, 13: 497501.

Bibus, E. (1980): Zur Relief-, Boden- und Sedimententwicklung am unteren Mittelrhein. - Frankfurter Geowissenschaftliche Arbeiten, Serie D, 1: 1-296.

Blanchard, H. (2002): Neue Erkenntnisse zur Eruptions- und Landschaftsgeschichte des Rodderbergs bei Bonn. - Unpublished Diploma thesis, Geographisches Institut der Rheinischen Friedrich-Wilhelms-Universität Bonn: $109 \mathrm{~S}$.

Bogatrd, P. v. d. \& Schmincke, H.-U. (1990): Die Entwicklungsgeschichte des Mittelrheinraumes 
und die Eruptionsgeschichte des Osteifel-Vulkanfeldes. - In: W. Schirmer (ed.): Rheingeschichte zwischen Mosel und Maas, DEUQUAFührer 1: 166-190.

Büchel, G. \& Lorenz, V. (1984): Zum Alter des Meerfelder Maares. - In: IrIon, G. \& NeGENDANK, J.F.W. (eds.): Das Meerfelder Maar. Untersuchungen zur Entwicklungsgeschichte eines Eifelmaares. - Courier Forschungsinstitut Senckenberg, 65: 13-15.

Büchel, G., Negendank, J.W.F., Wuttke, M. \& ViereCK-Götte, L. (2000): Quartäre und tertiäre Maare der Eifel, Enspel (Westerwald) und Laacher See: Vulkanologie, Sedimentologie und Hydrogeologie (Quaternary and Tertiary Eifel maars, Enspel (Westerwald) and Laacher See: Volcanology, sedimentology and hydrogeology.). - In: Neuffer, F.O. \& Lutz, H. (eds.): Exkursionsführer Internationale Maartagung, Daun / Vulkaneifel, 17-27. August 2000. Mainzer Naturwissenschaftliches Archiv, Beiheft 24: 85-123.

Chen, Y.-G., Wu, W.-S., Chen, C.-H. \& Liu, T.-K. (2001): A date for volcanic eruption inferred from a siltstone xenolith. - Quaternary Science Reviews, 20: 869-873.

Duller, G. (2006): Comment on "Human footprints in Central Mexico older than 40,000 years" by S. González, D. Huddart, M.R. Bennett and A. González-Huesca. - Quaternery Science Reviews, 25: 3074-3076.

Fattahi, M. \& Stokes, S. (2003): Dating Volcanic and Related Sediments by Luminescence Methods: A Review. - Earth-Science Reviews, 62: 229-264.

Fuchs, M., Straub, J. \& Zöller, L. (2005): Residual luminescence signals of recent river flood sediments: A comparison between quartz and feldspar of fine- and coarse-grain sediments. - Ancient TL, 23: 25-30.

Gonzáles, S., Huddart, D. Bennet, M.R. \& GonZÁlez-HuesCA, A. (2006): Human footprints in Central Mexico older than 40,000 years. Quaternery Science Reviews, 25: 201-222.

Grögler, N., Houtermans, F. G. \& Stauffer, H. (1960): Über die Datierung von Keramik und Ziegel durch Thermolumineszenz. - Helvetica Physica Acta (Compte rendue de la réunion de la Société Suisse de Physique), 33: 595-596.

Jain, M., Bøtter-Jensen, L., Murray, A.S., Denby, P.M., Tsukamoto, S. \& Gibling, M.R. (2005): Revisiting TL: Dose measurement beyond the OSL range using SAR. - Ancient TL, 23: 9-24.
Juvigné, E., Boenigk, W., Brunnacker, K., DuchESNE, J.-C. \& Windheuser, H. (1988): Zur Schlotfüllung des Hinkelmaars (Eifel, Deutschland): Alter und Genese. - Neues Jahrbuch für Geologie und Paläontologie; Monatshefte, 1988/9: 544-562.

Lamothe, M., Auclair, Hamzaoui, C. \& Hout, S. (2003): Towards a prediction of long-term anomalous fading of feldspar IRSL. - Radiation Measurements, 37: 493-498.

LeYK, H.-J. \& Lippolt, H.J. (1997): ${ }^{40} \mathrm{Ar} /{ }^{39} \mathrm{Ar}-$ Untersuchungen an spätquartären Vulkaniten der Eifel - Neue Arbeitsansätze zur Datierung junger Lavaströme. - Berichte der Deutschen. Mineralogischen Gesellschaft, Beihefte zum Europäischen Jahrbuch für Mineralogie, 11/1: $145 \mathrm{~S}$.

Lorenz, V. \& Zimanowski, B. (2000): Vulkanologie der Maare der Westeifel (Volcanology of the West Eifel Maars). - In: Neuffer, F.O. \& Lutz, H. (eds.): Exkursionsführer Internationale Maartagung, Daun / Vulkaneifel, 17-27. August 2000. - Mainzer Naturwissenschaftliches Archiv, Beiheft 24: 5-51.

Mejdahl, V. (1985a): Thermoluminescence dating based on feldspars. - Nuclear Tracks Radiation Measurements, 10: 133-136.

MejDahl, V. (1985b): Thermoluminescence dating of partially bleached sediments. - Nuclear Tracks Radiation Measurements, 10: 711-715.

MejDahl, V. (1988): The plateau method for dating partially bleached sediments by thermoluminescence. - Quaternary Science Reviews, 7: 347348.

Meyer, W. (1986): Geologie der Eifel. - 614 S; Stuttgart (E. Schweizerbart'sche Verlagsbuchhandlung).

Negendank, J.F.W. \& ZolitschKa, B. (eds.) (1993): Paleolimnology of European Maar Lakes. - Lecture Notes of Earth Sciences, 49: 513 S.; Berlin Heidelberg (Springer).

Paulick, H., Ewen, C., Blanchard, H. \& Zöller, L. (2008): The Middle Pleistocene Rodderberg maar-scoria cone Volcanic Complex (Bonn, Germany): eruptive history, geochemistry, and thermoluminescence dating. - International Journal of Earth Sciences / Geologische Rundschau, 98: 1879-1899. DOI 10.1007/s00531-008-0341-0.

Prescott, J.R. \& Hutton J.T. (1994): Cosmic ray contributions to dose rates for luminescence and ESR dating: large depths and long-term time variations. - Radiation Measurements, 23: $497-$ 500 . 
Richter, D. \& KrbetscheK, M. (2006): A new thermoluminescence dating technique for heated flint. - Archaeometry, 48: 695-705.

Ritter, J.R.R., Jordan, M., Christensen, U.R. \& Achauer, U. (2001): A mantle plume below the Eifel volcanic fields, Germany. - Earth Planetary Science Letters, 186: 7-14.

Schmincke, H.-U. (2000): Vulkanismus. - 264 S.; Darmstadt (Wissenschaftliche Buchgesellschaft).

Singhvi, A.K., Banerjee, D., Pande, K., Gogte, V. \& VALDIYA, K.S. (1994): Luminescence studies on neotectonic events in South-Central Kumaun Himalaya - a feasibility study. - Quaternary Science Reviews, 13: 595-600.

Sirocko, F., Seelos, K., Schaber, K., Rein, B., Dreher, F., Diehl, M., Lehne, R., Jäger, K. \& Krbetscher, M. (2005): A late Eemian aridity pulse in central Europe during the last glacial inception. - Nature, 436: 833-836.

Takeuchi, A., Hiroyuki N. \& Hashimoto T. (2006): Surface resetting of thermoluminescence in milled quartz grains. - Radiation Measurements, 41: $826-830$.

Vandenberghe, D., Kasse, C., Hossain, S.M., de Corte, F., Van den houte, P., Fuchs. M. \& MurRaY, A.S. (2004): Exploring the method of optical dating and comparison of optical and ${ }^{14} \mathrm{C}$ ages of Late Weichselian coversands in the southern Netherlands. - Journal of Quaternary Science, 19: 73-86.

WAGNER, G.A. (1998): Age Determination of Young Rocks and Artifacts. - 466 S.; Berlin, Heidelberg (Springer).

Westgate, J.A. (1988): Isothermal plateau fissiontrack age of the Late Pleistocene Old Crow Tephra, Alaska. - Geophysical Research Letters, 15: 376-379.

WintLe, A.G. (1973): Anomalous fading of thermoluminescence in mineral samples. - Nature, 245: 143-144.

WinTLE, A.G. (1998): Luminescence dating: Laboratory procedures and protocols. - Radiation Measurements, 27: 769-817.
Wintle, A.G. \& Huntley, D.J. (1980): Thermoluminescence dating of ocean sediments. - Canadian Journal of Earth Sciences, 17: 348-360.

WodA, C. (2000): Elektronen-Spin-Resonanz-Datierung von Quarz. - Unpublished PhD Thesis, Mathematisch-Naturwissenschaftliche Fakultät, Universität Heidelberg: 156 S.

Xie, J. \& Aitken, M.J. (1991): The hypothesis of mid-term fading and its trial on Chinese loess. Ancient TL, 9: 21-15.

ZIMMERMAN, D.W. (1971): Thermoluminescence dating using fine grains from pottery. - Archaeometry, 13: 29-52.

ZolitschKa, B., Brauer, A., Negendank, J.F.W., Stockhausen, H. \& Lang, A. (2000): Annually Dated Late Weichselian Continental Paleoclimate Record from the Eifel, Germany. - Geology, 28: 783-786.

ZöLler, L. (1989): Das Alter des Mosenberg-Vulkans in der Vulkaneifel. - Die Eifel, 84: 415-418.

ZÖLLER, L. (1995): Würm- und Rißlößstratigraphie und Thermolumineszenz-Datierung in Süddeutschland und angrenzenden Gebieten. - Habilitation thesis, Fakultät für Geowissenschaften Universität Heidelberg, (Nachtrag 1998; with extended English summary): http://www.aber. ac.uk/ancient-tl/

Zöller, L., Blanchard, H. \& McCammon, C. (2009): Can phonon assisted hydrostatic pressure reset the ambient TL of rocks? - A note on the TL of partially heated country rock. - Ancient TL: Ancient TL, 27: 15-22.

ZÖller, L. \& PernicKa, E. (1989): A note on overcounting in alpha-counters and its elimination. - Ancient, 27: 15-22

Zöller L. \& Wagner G.A. (1989): Strong or partial thermal washing in TL-dating of sediments? - In: Aitken; M. J. (ed.): Long \& Short Range Limits in Luminescence Dating. - Occasional Publication of the Research Laboratory for Archaeology and the History of Art, Oxford University; 9: $16 \mathrm{~S}$. (not paginated). 